\title{
GENETICS OF EUGLOSSINI BEES (HYMENOPTERA) IN FRAGMENTS OF THE ATLANTIC FOREST IN THE REGION OF VIÇOSA, MG
}

\author{
WALDSCHMIDT, A. M., ${ }^{1}$ LOPES, L. A., ${ }^{2}$ MARCO JR., P. ${ }^{2}$ and CAMPOS, L. A. O. ${ }^{2}$ \\ ${ }^{1}$ Departamento de Ciências Biológicas, Universidade Estadual do Sudoeste da Bahia (UESB), \\ Campus de Jequié, CEP 45200-000, Jequié, BA, Brazil \\ ${ }^{2}$ Departamento de Biologia Geral, Universidade Federal de Viçosa (UFV), CEP 36571-000, Viçosa, MG \\ Correspondence to: Ana Maria Waldschmidt, Departamento de Ciências Biológicas, Universidade Estadual do \\ Sudoeste da Bahia (UESB), Campus Jequié, CEP 45200-000, Jequié, BA, Brazil, e-mail: amaria@uesb.br \\ Received May 9, 2003 - Accepted November 11, 2003 - Distributed August 31, 2005
}

(With 6 figures)

\begin{abstract}
With uncontrolled deforestation, forest fragments remain, which in most cases are in different stages of regeneration and present isolated populations. In the present study we analyzed the genetic patterns of Eulaema nigrita populations in seven Atlantic Forest fragments of different sizes and successional stages in the region of Viçosa, MG. This was done by RAPD molecular markers. We observed that the area of the fragments had no effect on the genetic variability of E. nigrita in the direction predicted by meta-population models. Medium-sized well-preserved woods presented the lowest variability, whereas large and small woods were statistically identical. The evidence supports the notion that rural areas present greater dispersal among fragments, implying greater similarity between the populations of fragments located in rural areas when compared to fragments in urban areas.
\end{abstract}

Key words: Euglossini, fragments of wood, genetic structure, RAPD.

\section{RESUMO}

\section{Genética de abelhas Euglossini (Hymenoptera) em fragmentos de Mata Atlântica da região de Viçosa, MG}

Com o desmatamento descontrolado das florestas há a formação de fragmentos de mata que, na maioria das vezes, se encontram em distintos estágios de regeneração, mantendo populações isoladas. Neste trabalho foi feita a análise dos padrões genéticos de populações de Eulaema nigrita de fragmentos de mata Atlântica de diferentes tamanhos e estágios sucessionais por meio de marcadores moleculares RAPD da região de Viçosa, MG. Pode-se verificar que a área dos fragmentos não apresentou efeito sobre a variabilidade genética em E. nigrita na direção predita pelos modelos de metapopulação. Uma mata de tamanho médio e bem preservada apresentou a menor variabilidade, enquanto matas grandes e pequenas foram estatisticamente iguais. As evidências sustentam que áreas rurais apresentam maior dispersão entre fragmentos, implicando maior similaridade entre as populações de fragmentos localizados em áreas rurais se comparados com fragmentos nas áreas urbanizadas.

Palavras-chave: Euglossini, fragmentos de mata, estrutura genética, RAPD.

\section{INTRODUCTION}

A large part, comprising the entire Zona da Mata Mineira, of Minas Gerais State was covered with Atlantic forest up to the first half of the last century (Valverde, 1958). In the forest zone, the remains of the Atlantic Forest suffered a marked process of fragmentation as a consequence of expanded livestock breeding and coffee cultivation, in addition to the development of the lumber industry in the 1930s and 1940s. In the 1960s, the agricultural and livestock breeding activity in the forest zone allowed the gradual recovery of the forest cover. However, this has now been reduced to $8 \%$ of its 
original area (Couto \& Dietz, 1980). What remains is a set of forest fragments, in different regeneration stages that maintain isolated populations. These fragments for the most part measure from 2 to 10 ha in the region of Viçosa, MG, with only 4 fragments larger than 90 ha being left (as determined by aerial photography, CEMIG, 1987).

The reduction in population size due to habitat fragmentation can lead to reduced intrapopulation genetic variability. Increased inbreeding has been suggested as a possible reason for decreased resistance to disease, to an increase in geneticallybased diseases (Shaffer, 1981; Soulé \& Simberloff, 1986; Avise, 1992), or to decreased adaptability in components of populations when there are adaptive advantages for heterozygous organisms (Lacy, 1992).

Euglossinae bees are considered important pollinators of a variety of tropical species, especially orchids (Dressler, 1982; Roubik, 1991). In view of the fact that these bees can easily be collected (Campos et al., 1989) and are intimately related to the plants they visit, these species have been suggested as indicators of the conditions prevailing in forest fragments and have been used in the study of forest fragmentation (Powell \& Powell, 1987; Becker et al., 1991; Morato et al., 1992). Among these bees, Eulaema nigrita is a common species throughout most of Brazil, frequenting both open areas and forest fragment borders. It is a solitary species, large in size within the group, and has an apparently high ability to disperse.

The development of molecular marker techniques has led to a new phase in biodiversity study, demonstrating high potential for assessing the habitat fragmentation effect on the genetic structure of populations. Because of its ease in being carried out and the small amount of material required, the random amplified polymorphic DNA technique (RAPD) has been recommended by several authors and used in numerous studies (Landry et al., 1993; Shoemaker et al., 1994; Lu \& Rank, 1996; Suazo et al., 1998; Vasconcelos, 1998; Waldschmidt et al., 2000; Tavares et al., 2001; Almeida, 2002; Waldschmidt et al., 2002).

The objective of the present study was to analyze the genetic patterns of Eulaema nigrita by means of RAPD markers obtained for populations collected in a urbanized area (the campus of the Universidade Federal de Viçosa) and in a typical rural area in the same general region.

\section{MATERIAL AND METHODS}

\section{Characterization and location of the study areas}

The study was conducted in forest fragments in the region of Viçosa, MG. The main fragments are located around the center for the Study of Natural Forests, also called Paradise Wood $\left(20^{\circ} 45^{\prime} \mathrm{S}\right.$, $42^{\circ} 51^{\prime} \mathrm{W}$ ) and inside the campus of the Universidade Federal de Viçosa. The regional topology is strongly undulated, with altitudes ranging from 700 to 870 meters and declivity of $0^{\circ}$ to $60^{\circ}$.

The climate is of the CWA type (Köppen), i.e., moderately subtropical and humid, with a dry period from May to September and a rainy period from December to March. Mean annual rainfall is 1,500 to $2,000 \mathrm{~mm}$, relative humidity is about $80 \%$, and mean annual temperature ranges from a maximum of $26.1^{\circ} \mathrm{C}$ to a minimum of $14.0^{\circ} \mathrm{C}$ (Valverde, 1958).

Most of the fragments in the region result from secondary regeneration in areas that were periodically deforested as a result of coffee culture in the 1930 and 1940 decades. Many of these areas later started a progressive process of secondary regeneration, especially the Paraíso Wood. This natural regeneration process formed mosaics of vegetation that may represent different successional stages varying in complexity from brush to denser forests.

The sampled areas were forest fragments, which had suffered some type of perturbation and were in the process of secondary succession.

The largest wooded areas are Paraíso, Biologia, and Veterinária (Table 1). These fragments are within the UFV campus where they have been protected for at least 60 years, thus presenting better conservation. With respect to the pattern of area distribution of the fragments found in the region, Paraíso is the only large wooded area. Only one other fragment has a larger area in this region (São Geraldo Wood). The Biologia and Veterinária fragments are considered to be medium sized and the others are considered to be small. Most of the fragments in the Viçosa area are from 2 to 10 ha.

\section{Specimen capture and conservation}

To capture the specimens we used traps distributed approximately $2 \mathrm{~m}$ from one another and at least $30 \mathrm{~m}$ from the border of the wood, preferentially located in the middle of the fragment. The traps contained cineole as an attractant scent and were collected after 24 hours. 
TABLE 1

Area and characteristics of the forest fragments sampled in the region of Viçosa, MG.

\begin{tabular}{|c|c|c|c|}
\hline Fragments & Area (ha) & Location & Individuals \\
\hline Biologia Wood & 61.16 & University & 71 to 78 \\
\hline Veterinária Wood & 46.00 & University - rural area & 91 to 98 \\
\hline Meteorologia Wood & 11.30 & University - rural area & 81 to 88 \\
\hline Paraíso Wood & 344.17 & Rural area & 32 to 39 \\
\hline Vila Paraíso Wood & 9.50 & Rural area & 41 to 48 \\
\hline Palmital Wood & 8.67 & Rural area & 51 to 58 \\
\hline Prof. Alfredo Wood & 13.67 & Rural area & 61 to 68 \\
\hline
\end{tabular}

\section{DNA extraction and amplification}

Genomic DNA was extracted according to Waldschmidt et al. (1997) and amplified by PCRRAPD according to Williams et al. (1990). The reaction products were separated by electrophoresis on $1.2 \%$ agarose gel containing $10 \mu \mathrm{g} / \mathrm{ml}$ ethidium bromide immersed in TBE buffer $(90 \mathrm{mM}$ Trisborate, $1 \mathrm{mM}$ EDTA, $\mathrm{pH}$ 8.0). The DNA bands were visualized under ultraviolet light and photographed with a polaroid camera.

\section{Data analysis}

Genetic distance within a population and between populations was determined by the genetic distance of Nei \& Li (1979) using the following formula (eq. 1):

$$
\mathrm{SNL}=\frac{2 \mathrm{a}}{2 \mathrm{a}+\mathrm{b}+\mathrm{c}}
$$

in which: $\mathrm{a}=$ number of bands present in the two compared samples $(1,1) ; b=$ number of bands present in the first sample and absent in the second $(1,0)$; and $\mathrm{c}=$ number of bands absent in the first sample and present in the second $(0,1)$.

For grouping analysis we used the method of paired means (UPGMA) according to Manly (1994).

To test the hypothesis of genetic diversity among the populations studied we calculated the proportion of polymorphic bands (bands that presented variation in at least one individual sampled). To permit an appropriate statistical analysis, we used the jackknife procedure to estimate the proportion of polymorphic bands and their variance (Quenouille, 1956; Efron, 1981; Manly, 1991).

\section{RESULTS AND DISCUSSION}

We selected ten primers (OPB-06; OPB-19; OPE-14; OPL-17; OPM-09; OPM-13; OPN-20; OPP-06; OPQ-17; OPT-12) that produced 62 polymorphic bands.

Fig. 1 presents the individuals from a large fragment (Paraíso Wood) and from two small fragments (Vila Paraíso and Palmital Woods), which are close to one another in the rural zone. This comparison precludes establishing a pattern of similarity because of the apparent absence of genetic structure. Note that specimen 37 is isolated from the other specimens in this comparison.

Fig. 2 compares individuals from a medium-sized forest fragment (Biologia and Veterinária Woods) to those of a small fragment (Meteorologia Wood), which are located close to one another and within the university area (urban area). Grouping analysis showed higher similarity among the specimens present in the Biologia Wood and the presence of greater homogeneity between specimens of the Veterinária and Meteorologia Woods. Specimens 97, 95, and 88 presented approximately $80 \%$ similarity and were the individuals most distinct from one another and from the other individuals sampled.

Fig. 3 compares individuals from the large fragment (Paraíso Wood) to a medium one (Biologia Wood) and a small one (Prof. Alfredo Wood), only one of which is located inside the urban perimeter (Biologia Wood). The same figure also shows that the specimens of Biologia Wood are grouped. In addition, as in Fig. 1, only one specimen (39) was alone, being linked to the remaining specimens in this comparison. 


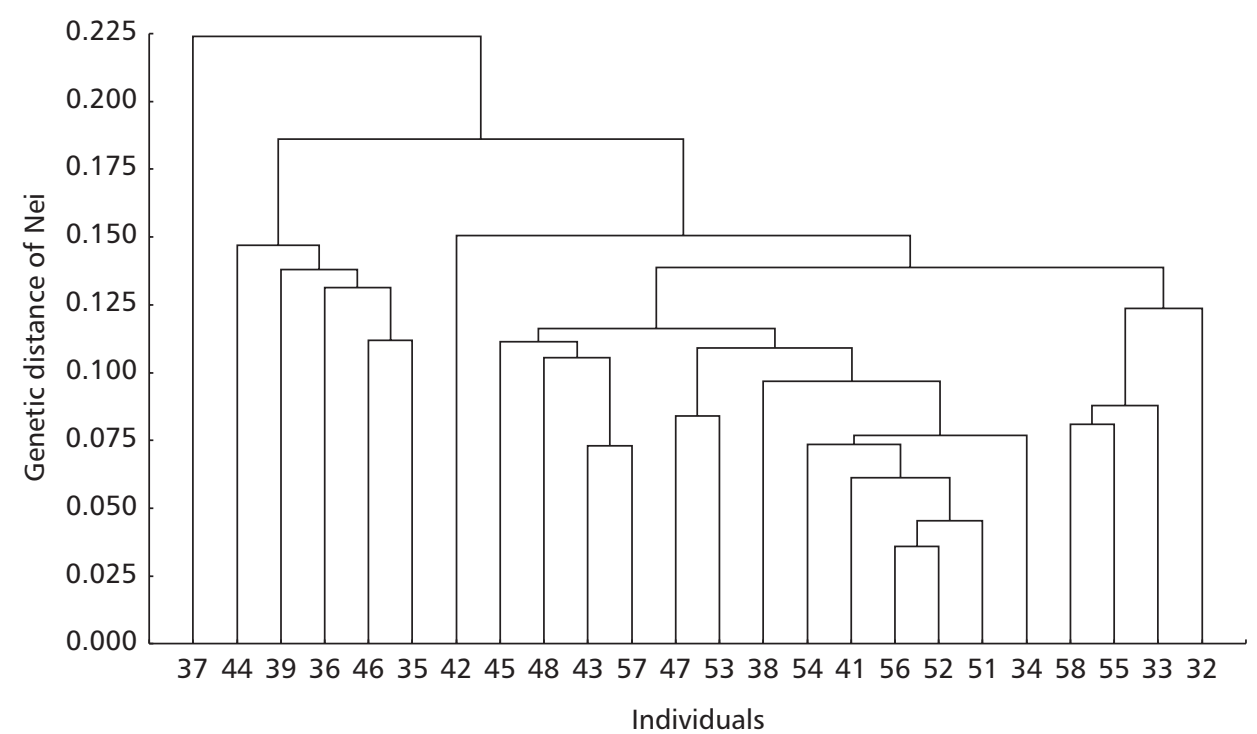

Fig. 1 - Grouping analysis by the UPGMA method of Nei-Li genetic distance; used for E. nigrita individuals collected in Paraíso Wood (32-39), Vila Paraíso Wood (41-48), and Palmital Wood (51-58).

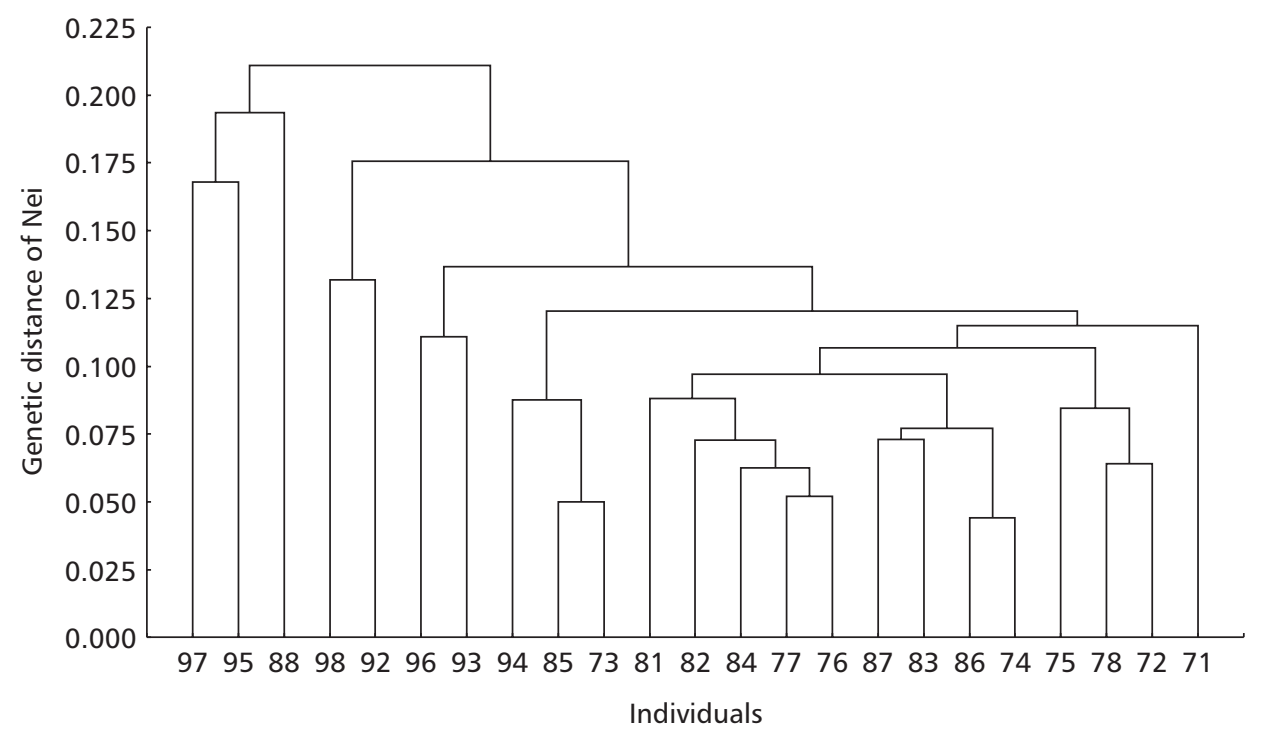

Fig. 2 - Grouping analysis by the UPGMA method of Nei-Li genetic distance; used for E. nigrita individuals collected in Biologia Wood (71-78), Meteorologia Wood (81-88), and Veterinária Wood (91-98). 
Fig. 4 compares individuals from small forest fragments, all located inside the urban perimeter, with two of them being close to one another (Palmital and Vila Paraíso Wood) and one more distant (Prof. Alfredo Wood). An apparently random distribution of the specimens was also observed, denoting the absence of a genetic structure. However, it should be pointed out that specimens 44 and 46 were apparently more distinct than the remaining specimens considered in this comparison.

Fig. 5 compares individuals from small fragments in the rural area (Palmital and Vila Paraíso Woods) with those from a more distant mediumsized wood located in the urban perimeter (Veterinária Wood). Great similarity between specimens (always higher than 85\%) was observed, even when there was an isolated specimen (41).

The results of the analysis of the proportion of polymorphic bands (Fig. 6) showed no evidence favoring the hypothesis that larger fragments present greater variability.

The results obtained for the Biologia Wood were exactly the contrary of what was expected. In the two comparisons, this wood presented a very small proportion of polymorphic bands. Similarly, there was no difference between the medium-sized and large forests and the two small woods in the Paraíso region. Only the Veterinária Wood showed a significant difference from the Palmital Wood.

Evidence that dispersal is greater in the rural area was supplied by the difference in variability between Biologia Wood and the neighboring woods (Veterinária and Meteorologia Woods) and the relative homogeneity of the wood in the Paraíso region.

There was no significant relation between fragment area and proportion of polymorphic bands as a measure of variability in each fragment $\left(\mathrm{R}^{2}=\right.$ $0.005 ; \mathrm{df}=1.5 ; \mathrm{F}=0.025 ; \mathrm{p}=0.880$ ).

Area and distance are two of the major descriptors used to explain species diversity (MacArthur \& Wilson, 1967; Simberloff \& Abele, 1982; McCoy \& Mushinsky, 1994), population dynamics (Adler, 1994; Aldaz, 1994) and genetic structure of populations (Avise, 1992; Carson, 1992; Wilmer et al., 1994) in natural fragments or in fragments resulting from man-made changes in landscape. However, a series of other factors of difficult control may influence the effect of fragmentation in natural populations. Among them are the bionomic aspects of the species under study, the spatial structure of fragments, the difference in shape among fragments, the border effect, the types of soil use in the matrix between the fragments, and existing altitude barriers against dispersal.

Thus, experiments designed to reveal results of fragmentation may fail to explain natural phenomena because of multiple variables not observed by experimental methodology. Nevertheless this approach was used in the first large-scale studies of the Biological Dynamics of Forest Fragments Project (Bierregaard et al., 1992). On the other hand, analysis of natural patterns may present a set of factors so complex that interpreting their causes may be extremely difficult. With respect to Biologia Wood, for example, the discrepancy in variability found may be an effect of area, of distance from nearby fragments, or of the conservation state of the system of the system itself.

In the present study, the area of the fragment did not influence the direction of theoretical predictions. On the contrary, a medium-sized fragment in a good state of conservation (Biologia Wood) was the one that presented the lowest number of polymorphisms in the bands studied.

E. nigrita is a species mainly found along the borders of more primary systems (e.g., Amazon forest) (Morato, 1994). However, in the Viçosa region this species can be found in relative abundance even within the fragments studied, possibly indicating a greatly altered state of the systems to the point at which the forest is open to colonization.

It is possible that, since an urbanized matrix separates the Biologia Wood from the majority of the other fragments, a small and isolated population of low variability has developed there. However, the high dispersal ability of these insects (Willians \& Dodson, 1972; Roubik, 1991) and the existence of pastures separating some areas of the Biologia Wood from the other fragments do not support this hypothesis. Furthermore, in the present study we detected a high frequency of polymorphisms in the populations of Veterinária Wood and Meteorologia Wood, which are sufficiently close for dispersal to occur between them.

The population in the Paraíso region (Paraíso, Palmital, and Vila Paraíso Woods) presented higher homogeneity in individuals than did the population of the university region (Biologia, Veterinária, and Meteorologia Woods). 


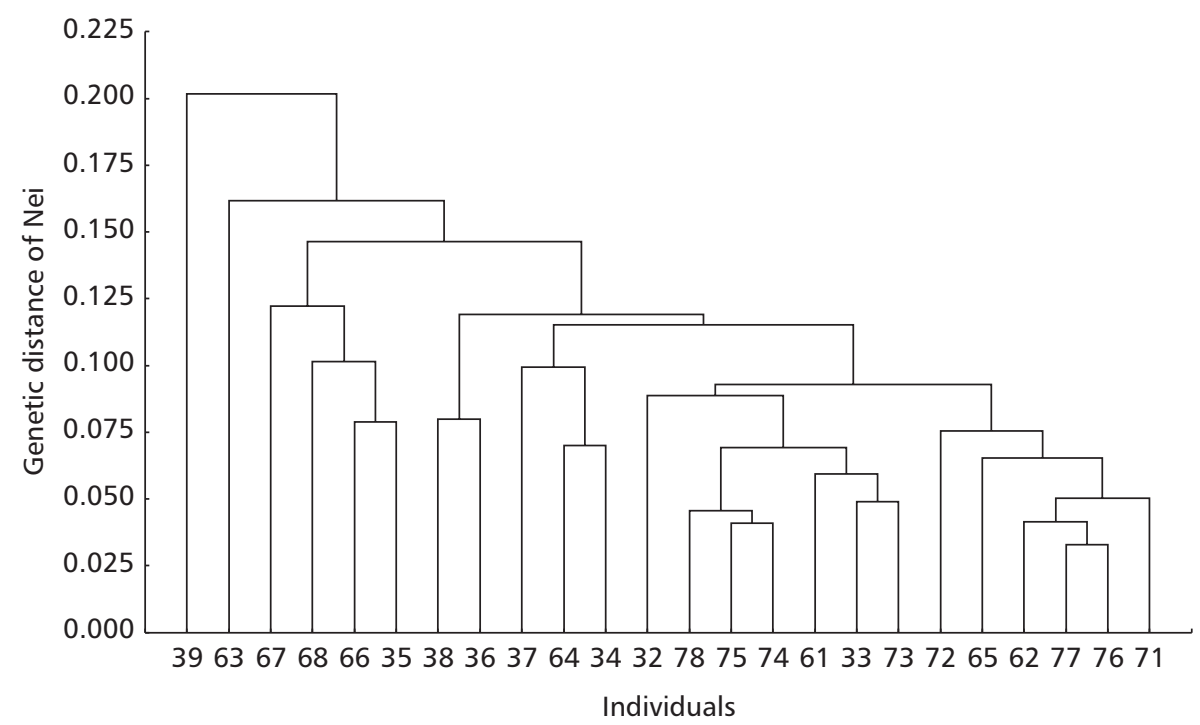

Fig. 3 - Grouping analysis by the UPGMA method of Nei-Li genetic distance; used for E. nigrita individuals collected in Biologia Wood (71-78), Paraíso Wood (32-39), and Prof. Alfredo Wood (61-68).

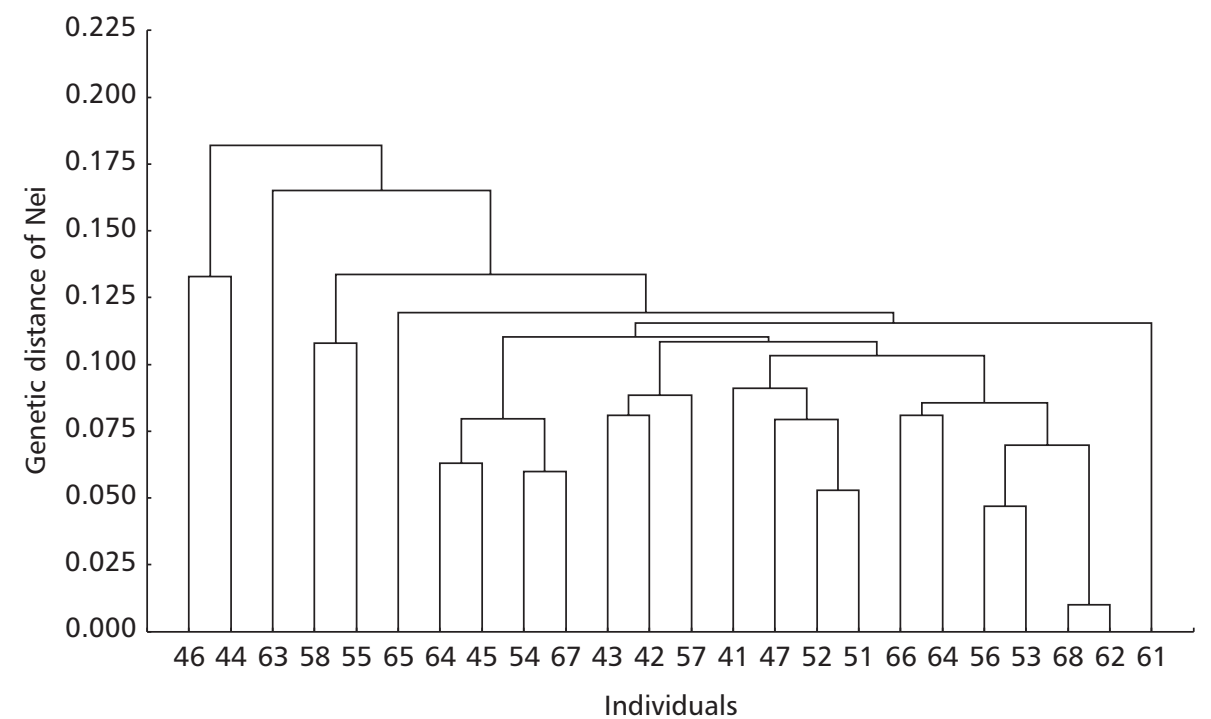

Fig. 4 - Grouping analysis by the UPGMA method of Nei-Li genetic distance; used for E. nigrita individuals collected in the Prof. Alfredo Wood (61-68), Palmital Wood (51-58), and Vila Paraíso Wood (41-48). 


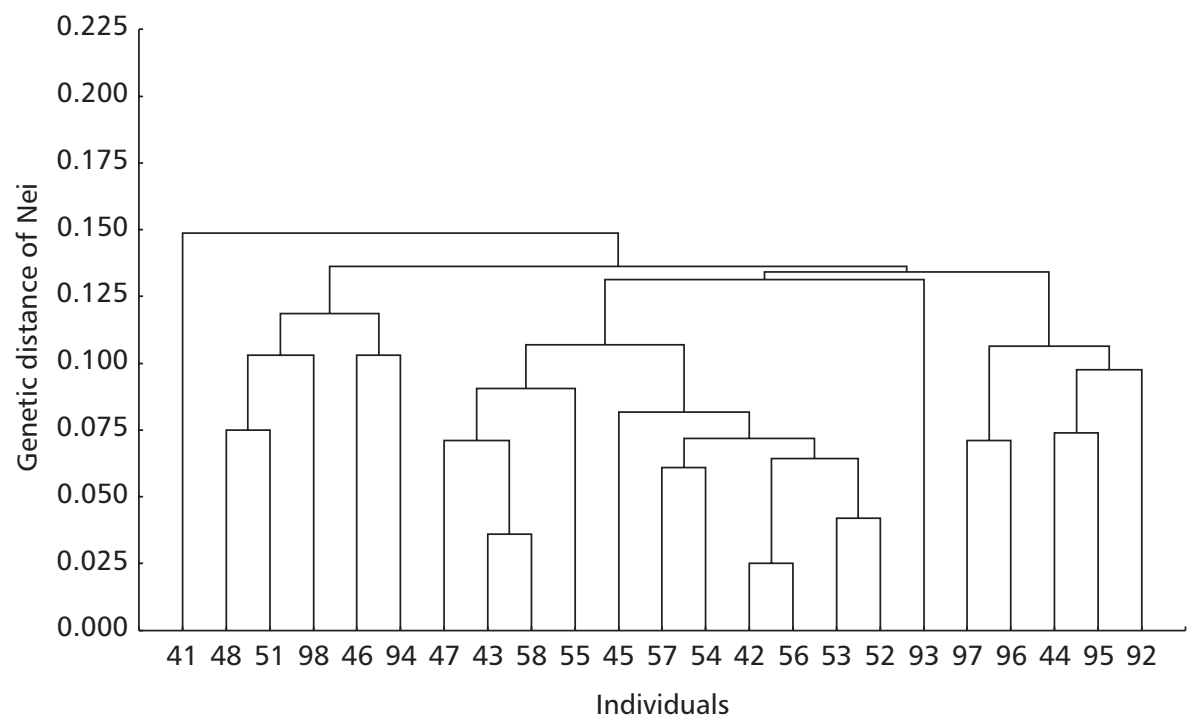

Fig. 5 - Grouping analysis by the UPGMA method of Nei-Li genetic distance; used for E. nigrita individuals collected in Veterinária Wood (91-98), Palmital Wood (51-58), and Vila Paraíso Wood (41-48).

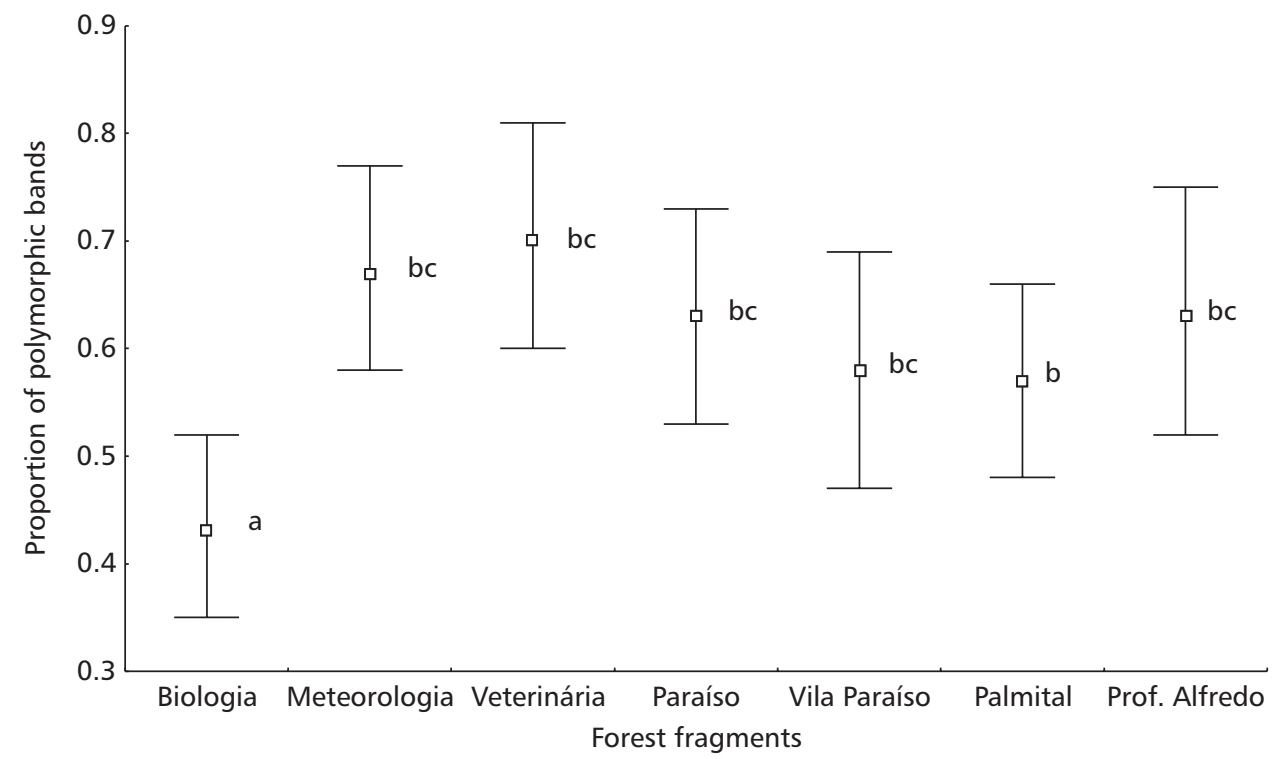

Fig. 6 - Proportion of polymorphic bands estimated by the jackknife method for E. nigrita populations in the forest fragments studied. 
The difference found between the individuals sampled in populations of the urban and the rural areas strengthens the hypothesis of greater dispersal among the rural area fragments, which could be explained by the existence of a common matrix.

In conclusion, the area of the fragments proved to have no effect on the genetic variability of E. nigrita to the extent predicted by metapopulation models. The medium-sized wellpreserved forest presented lower variability, while large and small forests were statistically identical. The evidence supports the notion that rural areas present greater dispersal among fragments, implying greater similarity between the populations of fragments located in rural areas when compared to fragments in urban areas.

Acknowledgements — We are grateful to Tânia Maria Fernandes Salomão and Vander Tosta for valuable criticism and suggestions. This research was supported by Fundação de Amparo à Pesquisa do Estado de Minas Gerais (FAPEMIG), the National Counsel of Technological and Scientific Development (CNPq), and the Universidade Estadual do Sudoeste da Bahia.

\section{REFERENCES}

ADLER, G. H., 1994, Tropical forest fragmentation and isolation promote asynchrony among populations of a frugivorous rodent. J. Anim. Ecol., 63(4): 903-911.

ALDAZ, J. M., 1994, Habitat destruction and the dynamics of metapopulations. J. of Anim. Ecol., 63(2): 492-493.

ALMEIDA, E. A. B., 2002, Diversidade e estrutura genética de populações de duas espécies de Euglossini (Hymenoptera: Apidae) em florestas fragmentadas na região metropolitana de Belo Horizonte, MG. Dissertação de Mestrado, Universidade Federal de Minas Gerais, Belo Horizonte.

AVISE, J. C., 1992, Molecular population structure and the biogeographic history of a regional fauna: a case history with lessons for conservation biology. Oikos, 63(1): 62-76.

BECKER, P., MOURE, J. S. \& PERALTA, F. J. A., 1991, More about Euglossine bees in amazonian forest fragments. Biotropica, 23(4b): 586-591.

BIERREGAARD JR., R. O., LOVEJOY, T. E., KAPOS, V., SANTOS, A. A. \& HUTCHINGS, R. W., 1992, The biological dynamics of tropical rainforest fragments: a prospective comparison of fragments and continuous forest. BioScience, 42(11): 859-866.

CAMPOS, L. A. O., SILVEIRA, F. A., OLIVEIRA, M. L., ABRANTES, C. V. M., MORATO, E. F. \& MELO, G. A. R., 1989, Utilização de armadilhas para a captura de machos de Euglossini (Hymenoptera, Apoidea). Rev. Bras. Zool., 6(4): 621-626.
CARSON, H. L., 1992, Genetic change after colonization. Geojournal, 28(2): 297-302.

CEMIG, 1987, Levantamento aerofotogramétrico de Viçosa, MG. Companhia Energética de Minas Gerais. Levantamento aerofotogramétrico. Escala 1:10.000.

COUTO, E. A. \& DIETZ, J. M., 1980, Sugestões para a criação do Parque Nacional da Serra do Brigadeiro. Imprensa Universitária/Universidade Federal de Viçosa, Viçosa, MG, $26 \mathrm{p}$.

DRESSLER, R. L., 1982, Biology of the orchid bees (Euglossini). Ann. Rev. Ecol. Syst., 13: 373-394.

EFRON, B., 1981, Nonparametric standard errors and confidence intervals. The Can. J. of Stat., 9: 139-172.

EFRON, B., 1982, The jackknife, the bootstrap and other resampling plans. Society for Industrial and Applied Mathematics, Philadelphia, 92p.

LACY, R. C., 1992, The effects of inbreeding on isolated populations: are minimum viable population sizes predictable? pp. 277-296. In: P. L. Fiedler \& S. K. Jain (eds.), Conservation Biology. The Theory and Practice of Conservation. Preservation and Management. Chapman and Hall, NY.

LANDRY, B. S., DEXTRAZE, L. \& BOIVIN, G., 1993, Random amplified polymorphic DNA markers for DNA fingerprinting and genetic variability assessment of minute parasitic wasp species (Hymenoptera: Mymaridae and Trichogrammatidae) used in biological control programs of phytophagous insects. Genome, 36: 580-587

LU, R. \& RANK, G. H., 1996, Use of RAPD analyses to estimate population genetic parameters in the alfalfa leaf-cutting bee, Megachile rotundata. Genome, 39: 655-663.

MACARTHUR, R. H. \& WILSON, E. O., 1967, The theory of island biogeography. Princeton University Press, Princeton, 203 p.

MANLY, B. F. J., 1991, Randomization and Monte Carlo methods in biology. Chapman and Hall, London, 281p.

Manly, B. F. J., 1994, Multivariate statistical methods: a primer. Chapman and Hall, London, 215p.

McCOY, E. D. \& MUSHINSKY, H. R., 1994, Effects of fragmentation on the richness of vertebrates in the Florida scrub habitat. Ecology, 75(2): 446-457.

MORATO, E. F., 1994, Abundância e riqueza de machos de Euglossini (Hymenoptera: Apidae) em mata de terra firme e áreas de derrubada, nas vizinhanças de Manaus (Brasil). Bol. Mus. Par. Emíl. Goel., sér. Zool., 10: 95-105.

MORATO, E. F., CAMPOS, L. A. O. \& MOURE, J. S., 1992, Abelhas Euglossini (Hymenoptera, Apidae) coletadas na Amazônia Central. Rev. Bras. Entom., 36: 767-771.

NEI, M. \& LI, W. H., 1979, Mathematical model for studying genetic variation in terms of restriction endonucleases. Proc. Nat. Academy Sci. USA, 76: 5269-5273.

POWELL, A. H. \& POWELL, G. V. N., 1987, Population dynamics of male Euglossine bees in Amazonian forest fragments. Biotropica, 19: 176-179. 
QUENOUILLE, M. H., 1956, Notes on bias in estimation. Biometrika, 43: 353-360.

ROUBIK, D. W., 1991, Ecology and natural history of tropical bees. Cambridge University Press, Cambridge, 514p.

SHAFFER, M. L., 1981, Minimum population sizes for species conservation. BioScience, 31: 131-134.

SHOEMAKER, D. D., COSTA, J. T. \& ROSS, K. G., 1994, Estimates of heterozygosity in two social insects using a large number of electrophoretic markers. J. Heredity, 69: 573-582.

SIMBERLOFF, D. \& ABELE, L. G., 1982, Refuge design and island biogeographic theory: effects of fragmentation. Amer. Nat., 120(1): 41-50.

SOULÉ, M. E. \& SIMBERLOFF, D., 1986, What do genetics and ecology tell us about the design of nature reserves? Biol. Cons., 35: 19-40.

SUAZO, A., MCTIERNAN, R. \& HALL, H. G., 1998, Differences between African and European honey bees (Apis mellifera L.) in random amplified polymorphic DNA (RAPD). J. Heredity, 89: 32-36.

TAVARES, M. G. E., RIBEIRO, E. H., CAMPOS, L. A. O. BARROS, E. G. \& OLIVEIRA, M. T. V., 2001, Inheritance pattern of RAPD markers in Melipona quadrifasciata (Hymenoptera: Apidae, Meliponinae). J. Hered., 92: 279282.

VALVERDE, O., 1958, Estudo regional da Zona da Mata de Minas Gerais. Rev. Bras. Geog., 20: 3-79.
VASCONCELOS, S. M., 1998, Divergência genética entre populações de M. rufiventris (Hymenoptera, Apidae, Meliponinae). Dissertação de Mestrado em Genética e Bioquímica, Universidade Federal de Uberlândia, Uberlândia, $49 \mathrm{p}$

WALDSCHMIDT, A. M., SALOMÃO, T. M. F., BARROS, E. G. \& CAMPOS, L. A. O., 1997, Extraction of genomic DNA from Melipona quadrifasciata (Hymenoptera: Apidae, Meliponinae). Rev. Bras. Genét., 20(3): 421-423.

WALDSCHMIDT, A. M., BARROS, E. G. \& CAMPOS, L. A. O., 2000, A molecular marker distinguishes subspecies Melipona quadrifasciata quadrifasciata and Melipona quadrifasciata anthidioides (Hymenoptera: Apidae, Meliponinae). Braz. Gen., 23(3): 609-611.

WALDSCHMIDT, A. M., BARROS, E. G. \& CAMPOS, L. A. O., 2002, Genetic analisys of Melipona quadrifasciata Lep. (Hymanoptera: Apidae, Meliponinae) with RAPD markers. Braz. J. Biol., 62(4B): 923-928.

WILliAMS, J. G. K., KUBELIK, A. R., LIVAK, K. J., RAFALSKI, J. A. \& TINGEY, S. V., 1990, DNA, polymorphisms amplified by arbritary primers are useful as genetic markers. Nuc. Acids Res., 18: 6531-6535.

WILLIANS, N. H. \& DODSON, C. H., 1972, Selective attraction of male euglossine bee to orchid floral fragrance and its importance in long distance pollen flow. Evolution, 26: 8495.

WILMER, J. W., MORITZ, C., HALL, L. \& TOOP, J., 1994, Extreme population structuring in the threatened ghost bat, Macroderma gigas: evidence from mitochondrial DNA. Proc. Roy. Soc. London, Series B, 257: 193-198. 